\title{
In search of liberalism: Ideological traditions, translations, and troubles in Thailand
}

\author{
TOMAS LARSSON \\ University of Cambridge
}

\begin{abstract}
The history of political thought in Southeast Asia has overwhelmingly focused on nationalism and socialism/Marxism. Little has been written about the fate of liberalism in the region. This is in stark contrast with the literature that in recent years has emerged on liberal political thought in South Asian and East Asian contexts. Seeking to make a Southeast Asian contribution to this literature, this article asks: Is there liberalism in Thailand? To answer the question, it surveys the existing literature on Thai political thought; outlines the history of the reproduction of the Western liberal canon in Thai translation; and takes stock of contemporary political debates. What does it find? First, that while one might find liberals in Thai history, there is no liberalism. Second, that serious intellectual engagement with liberal political thought occurs comparatively late and remains modest in Thailand, but that Thai politics nevertheless has been stalked by the spectre of Rousseau for more than eight decades. Third, and finally, that some Thai intellectual historians and other writers have responded to the country's recent political troubles - in the form of increasing political polarization, intractable and often violent conflict, two military coups, and the ill health and subsequent death of King Bhumibol - by laying the intellectual groundwork for a liberal form of Thai nationalism.
\end{abstract}

Keywords: Liberalism; ideology; political thought; intellectual history; Thailand 
In the late 1800s, the German sociologist Werner Sombart asked a classic question of comparative historical sociology that has continued to generate debate ever since: Why is there no socialism in the United States? Likewise, in the early stages of the Cold War, when almost all Southeast Asian countries saw the eruption of Communist insurgencies, scholars sought to explain the exception of Thailand (Thompson and Adloff 1950). This essay addresses a similar kind of question, focused on another revolutionary ideology: liberalism. The conventional wisdom holds that, "In Southeast Asia, the influence of classical political liberalism is extraordinarily limited" (Rodan and Hughes 2014, p. 6) - and in this instance Thailand is no exception. Yet liberalism's sorry fate in Southeast Asia has largely been taken for granted by scholars, with few puzzling over its causes or questioning its veracity.

This essay proposes that it is time to reconsider this dismissive attitude towards liberalism. The history of liberal political thought in Asia has yet to be written, but important pieces to the puzzle have been put into place. To date, however, the endeavor has been focused squarely on South and East Asia (Bayly 2011; Nolte 1987; Fung 2008; Moon 2014), while Southeast Asia, except for the Philippines (Claudio 2017), has been overlooked. Consequently, there is an opportunity to contribute to this growing literature by recovering the history of liberalism in Southeast Asia. Even if the search for Southeast Asian liberalism in the end were to leave us with meagre rewards, the literature on liberalism in other parts of Asia suggests that the (relative) absence of a meaningful liberal tradition in Southeast Asia cannot be easily dismissed by a wave of the hand in the direction of colonialism and ostensibly Asian values.

The main objective of this is essay is to add another piece to the jigsaw, by seeking to shed light on the fate of liberalism in one Southeast Asian country - Thailand (or Siam, as it was previously known). As a first step, it combs through the literature on Thai political thought. What 
evidence, if any, can we find of a liberal tradition therein? As a second step, the search moves beyond Thai thinkers. To what extent has liberalism been reproduced in Thailand through the translation and publication of works belonging to the Western liberal canon? As a third and final step, the search moves from the historical to the more recent past. To what extent has Thailand's recent political experience - turbulent, conflict-ridden, and repressive as it is - stimulated Thai intellectuals to turn towards liberalism in their search for solutions to their country's political woes?

The inquiry proceeds based on a specific understanding of what liberalism means. The approach taken here is sociologically inspired, and defines liberalism as a tradition that is constituted by the classification of prominent ideological entrepreneurs - and the arguments associated with them - as liberal by many scholars of political thought. ${ }^{1}$ Using this definition, liberalism as a distinct ideological tradition is a product of the intellectual labour performed by scholars who do research into and write and teach about politics in general and political thought in particular. It is through precisely such a process that a shared understanding has emerged about who is to be considered part of the Western liberal canon, with thinkers such as John Locke, John Stuart Mill, and John Rawls widely recognized as icons of liberalism.

While this essay thus has adopted a non-prescriptive definition of liberalism, it is of course true that scholars who work on political ideologies may conceptualize liberalism in (many) other ways. One such conception, falling short of a definition, will be useful to keep in

\footnotetext{
${ }^{1}$ This formulation draws on a definition recently proposed by Duncan Bell, but relaxes some of its conditions: "the liberal tradition is constituted by the sum of the arguments that have been classified as liberal, and recognised as such by other self-proclaimed liberals, across time and space" (Bell 2014, pp. 689-690, emphasis in original).
} 
mind as this essay progresses. Fawcett (2014, p. 10) conceives of liberalism as a "practice guided by four loose ideas." Those ideas can be summarized as follows: conflict is inescapable and social harmony unachievable; resistance to power, which tends towards domination, is necessary; social change for the better, i.e., progress, is possible and desirable; and, finally, respect for the individual (Fawcett 2014, pp. 10-11). While each of these ideas may be shared with other ideologies, it is their combination that contrasts liberalism with its ideological rivals, with socialism and conservatism most prominent among them.

While it would be an exaggeration to suggest that there is no liberalism to be found in Thailand, it is only a slight one. As I show in the next section, it accurately reflects the marginal position of liberalism in studies of Thai political thought and intellectual history. Whereas significant scholarly attention has been directed towards socialism and Marxism, on the one hand, and conservative "official" nationalism on the other hand, liberalism constitutes a virtually empty set in studies of Thai political thought. And as I then make clear, the introduction of Western liberal thought into Thai society was a much belated affair in world-historical perspective; it won few apparent major figures as converts; and has until recently attracted no serious scholarly attention. That is not to say that liberalism has no prospects in Thailand. As I note in the final empirical section, Thailand's political crisis is, in large part, the result of a cultural and ideological impasse, and recent writings by Thai ideological entrepreneurs can be understood as part of an effort to develop liberal alternatives to conservative conceptions of Thainess and of the appropriate social and political order. The essay concludes with some suggestions for further research on liberalism in Thailand and in Southeast Asia more broadly. 


\section{Socialism and conservatism, but no liberalism}

This essay was stimulated in large part by the simple observation that the literature on modern political thought in Thailand seemed to be focused almost entirely on conservatism and socialism. Situating Siam in regional perspective, Anderson (1977, pp. 20-21) observed that while "most Southeast Asian countries have inherited a political vocabulary and rhetoric which is essentially radical-populist, if not left-wing, in character," in Siam "[t]he prevailing rhetoric had typically been conservative, conformist and royalist." Within the scholarly literature, we generally find Thai conservatism (anurakniyom) analyzed and critiqued under the rubrics of official or royalist nationalism (Anderson 1990; Murashima 1988; Thongchai 2001). In addition to conservative nationalism, scholars who have engaged in some fashion with Thai political thought and intellectual history have tended to direct their efforts towards the radical socialist tradition in Thailand (Reynolds 1994; Kasian 2001; Thongchai 2008). As one might expect, these two strands of intellectual history have established rival canons and figures of authority. Thus, Thai $20^{\text {th }}$ century intellectual history can be depicted as a battle between the hegemonic conservatism articulated by figures like King Vajiravudh and Kukrit Pramoj and the socialisminflected counter-hegemonic ideological challenge led by radicals like Pridi Phanomyong and Chit Phumisak. But what of liberalism?

Anyone searching the library catalogues for major treatises on Thai liberalism does so in vain. True, one would have no trouble finding an important literature on concepts that often are thought of as closely related to liberalism. Most notably, scholars have explored the meaning and evolution of the concepts of freedom, liberty, and republicanism/democracy in the Thai context (Thanet 1998; Loos 1998; Jory 2015). But we do not find any clearly defined liberals therein, much less any liberalism. Moreover, in overviews of Thai political ideology we often find 
democracy (prachathipatai) - rather than liberalism (seriniyom) - juxtaposed against conservative nationalism and its Marxist/socialist rival (Peleggi 2007, chapter 4). But "democracy" is not a distinct ideological tradition, and prachathipatai has of course proved sufficiently flexible to be incorporated within both socialist and conservative ideologies (in Thailand as elsewhere). Other liberal-sounding words like seriphap (freedom) and sitthi (right) have experienced similar ideological appropriation across the ideological spectrum. Thus, one must not assume that the mere use of words such as prachathipatai, seriphap, or sitthi in political discourse are reliable indicators of political liberalism. As informative as conceptual histories are, they do not, separately or collectively, provide us with an account of liberalism's fate in modern Thailand.

The marginalization of liberalism in the intellectual history of Thailand is strikingly evident in several recent contributions. For instance, in Sopha Chanamun's (2007) study of how progressive intellectuals (panyachon huakaona) have viewed the Thai nation (chat thai) and how they have sought to challenge the mainstream (krasae lak) conservative notion of Thainess (khwam pen thai) one would naturally expect to find a discussion of the kingdom's liberal tradition - if one was thought to exist. But it is not. In fact, a single progressive is categorized as a liberal: the writer, newspaper editor, and novelist Malai Chuphinit. All the other progressive intellectuals are categorized as socialists or Marxists. ${ }^{2}$ What these progressive intellectuals, including the lonely liberal, have in common, according to Sopha (2007, p. 60), is their

\footnotetext{
${ }^{2}$ While he eventually ends up in the socialist/Marxist column, the early writings of Kulap Saipradit (i.e. around 1932) are identified by Sopha as examples of liberal thought. The other progressives profiled are Seni Saowaphong, Udom Sisuwan, Atsani Phonlachan, Supha Sirimanon, Pluang Wannasi, Thawip Woradilok, and Chit Phumisak.
} 
opposition to authoritarian government in Thailand, to Western imperialism and neocolonialism both at home and in Indochina, and to establishment interpretations of Thai history. The reason why Malai, author of the novel Thung maharat, is considered a liberal is not entirely clear, but Sopha (2007, p. 48) mentions that his writings demonstrate little apparent influence of Marxist theorizing, that he was "polite and gentle," and that he did not, unlike many of his fellow progressives, participate in public protests. It thus appears as if Malai's ideological position as a liberal is defined in large part by the things that he does not do: adopt Marxisant vocabulary, behave rudely, and join the so-called peace revolt (kabot santiphap) in 1952. With Malai the exceptional liberal among Thai progressive intellectuals, Sopha (2007, p. 116) notes that, "progressive thought" by the late 1940s had become a euphemism for Marxism.

Moving forward in time, Prajak Kongkirati (2015) has recently explored what he calls the "cultural politics" of the 1960s and 1970s, with a focus on the Thai student movement. Here one will occasionally encounter the ideological category liberalism, but it is never associated with any clearly identifiable political or intellectual protagonists. This is very much unlike the case for the representatives of the "old" and "new" Left, who take center stage in the narrative. Discussing the cultural afterlife of the student movement, Prajak notes that many of the ideologies that were popular during the heyday of the student movement in the 1970s have since faded or disappeared from view. The ideologies he has in mind are "socialism, communism, and liberalism (which has never had strong roots in Thai society)” (Prajak 2015, p. 255).

In Saichon Sattayanurak's magnum opus on the history of conservative nationalist thought in Thailand it is perhaps only to be expected that liberalism remains off center. Saichon (2014a; 2014b) traces the development of the Thainess discourse that became hegemonic in modern Thailand through a close analysis of the writings of the ten "fathers" of this ideological 
complex. They are, in order of appearance: King Chulalongkorn, King Vajiravudh; Prince Damrong Ratchanuphap; Prince-Patriarch Vajiranana; Chaophraya Thammasakmontri (Sanan Thephatsadin na Ayutthaya); Luang Wichit Wathakan; Phraya Anuman Rajadhon; Prince Wan Waithayakon Worawan; Mom Ratchawong Kukrit Pramoj; and, finally, Sulak Sivaraksa. The nationalist writings of these gentlemen are responding to more or less vaguely perceived intellectual challenges from within and without, starting with the 1885 petition for government reform by Prince Prisdang and his associates, famously critiqued by King Chulalongkorn, and ending with the economic liberalism and rationalism of Puay Ungpakorn that Sulak Sivaraksa rapped as un-Thai.

The illiberal position of these conservative intellectuals is readily apparent. To note just a few examples: Luang Wichit viewed nationalism as the very opposite of liberalism, which he associated with individualism, egoism, and growing class inequalities; Phraya Anuman considered the idea of human equality as no more than talk, and he argued that Thais already enjoyed freedom "in their hearts" and therefore had no reason to demand it; Kukrit viewed Thaistyle government centered on the king and the Buddhist conception of freedom as a spiritual matter superior to anything offered by Western-style liberal democracy; and Sulak, for his part, preferred rule by enlightened and moral elites - "good people" - over rule by the wealthy, greedy, and angry, which he saw as the inevitable outcome of Western-style liberal politics (Saichon 2014b, pp. 560-564).

It is never entirely clear, however, whether the intellectuals perceived as challenging conservative conceptions of the appropriate political and social order - from Prince Prisdang to Puay Ungphakorn - ought to be considered representatives of a liberal tradition of political thought. 
While Saichon's ten panyachon have been chosen for their contributions to the development of conservative Thai nationalism, some seem to fit rather awkwardly in the conservative camp. This is particularly the case for Prince Wan. While his influence on Thai conservative thought, through his role in the modernization of the Thai political vocabulary, cannot be denied, the same can and has been said about Prince Wan's influence on Marxist thought (Kasian 2001, pp. 196-198). Furthermore, many of his ideas about politics and Thai identity were never, as Saichon (2014b, p. 540) highlights, incorporated into the conservative mainstream. Prince Wan's ideas about social equality and human dignity were simply too liberal.

As we shall see soon, Prince Wan also played a pivotal role in the introduction of Western liberal thought in Siam in the 1930s. But here I should like to highlight that one of Prince Wan's young proteges, Chinda Phanthumchinda, wrote a 1938 book entitled Thammachariya-prachakhom: seriphap somoephap pharadonphap (Social morality: freedom, equality, fraternity) which, according to Suphachai Suphaphon (2013), contained liberal answers to basic political questions. It emphasized in particular the importance of the consent of the governed and individual freedom (Suphachai 2013, p. 181-184). This may in fact be the first major liberal tract written by a Thai author. If so, the hitherto forgotten Chinda, a Roman Catholic who later would take the last name Chintanaseri (meaning "free will”) (Suphachai 2013, pp. 187, 193), might deserve more widespread recognition as a pioneering Siamese liberal.

There is one important exception to the dearth of liberalism in studies of Thai political thought. Michael Connors has frequently deployed the category "liberalism" in his important contributions to the study of modern Thai politics. In short, he approaches the study of Thai democratization through a focus on an important discourse, unique to Thailand, that he labels "royal liberalism" (Connors 2008; 2012). However, this usage appears somewhat idiosyncratic. 
The intellectuals that Connors (2008, p. 145) associate with this discourse, with Kukrit Pramoj most prominent among them, are more commonly considered spokespersons for the conservative tradition highlighted by Anderson. Among scholars of Thai political history, the package of ideas they represent are generally understood less as a form of liberalism and more as a conservative attempt to fashion a Thai-style alternative to liberalism (see, for instance, Hewison and Kengkij 2010). As an ideological project, it has proven remarkably effective, as evidenced by the fact that the resultant liberalish monarchism on numerous occasions since the early 1970s has been found useful by forces opposed to dictatorships (military and parliamentary). The consequence has been a kind of ideological substitution effect: "no liberal-democratic nationalism developed [in Thailand] because the monarchical nationalism of King Bhumibol offered an alternative to the political nationalism of the military regimes" (Sturm 2006, p. 257). Thus, what Thailand got instead of liberalism was a new version of Thai conservatism which, at least occasionally, tolerated democratic forms and procedures such as elections and parliaments while continuing to reject fundamental liberal-democratic norms and values. To distinguish these "modernizers" of Thai conservatism from the purely reactionary, scholars have referred to this strand of conservatism by adding modifiers such as "progressive," "creative," and, indeed, "liberal" (Kershaw 1980; Zimmerman 1978, p. 65; Connors 2011, p. 668). Thus, there is no consensus in the scholarly literature that Connor's "royal liberalism" is liberalism at all.

The conclusion we may draw from the discussion so far, is that Thailand may have (a few) homegrown liberals, but it does not have liberalism. At least not in the same sense that it has socialism and conservatism. In the existing literature, both socialism and conservatism are easily recognizable intellectual currents (krasae) made up of successive generations of prominent ideological entrepreneurs. No equivalent exists for liberalism. However, in the process of 
arriving at this conclusion, we have also identified several exceptional individuals, such as Prince Wan, Chinda Chintanaseri, Malai Chuphinit, and Puay Ungpakorn, who do not seem to belong in either the socialist or the conservative camp, and who might deserve to be considered as liberals. It is through the close study of the political thought of figures such as these that a liberal tradition might conceivably be unearthed in Thailand. ${ }^{3}$

${ }^{3}$ I do not seek to deny that there are liberals in Thailand, if by that we simply mean persons who in some way or other think of or present themselves as liberals, or may be considered such by others. For instance, those who have voiced constitutional opposition to absolutism and dictatorship might be thought of as liberales in the original Spanish meaning of the term. Of course, civil society activists working on issues such as human rights may often be considered liberals in some sense (as they are in Bajpai and Bonura 2013). And there is no denying that Thailand's Democrat Party is a member of the Liberal International (LI), and that party leader Abhisit Vejjajiva in 2016 was elected chair of the LI-associated Council of Asian Liberals and Democrats. Nevertheless, the Democrat Party has often been considered a conservative party with some (but limited) liberal tendencies (Sungsidh 1996; Tomsa 2017). Furthermore, many Thai governments have of course pursued economic policies that have been labelled, usually by their critics, as "neoliberal." However, for the purposes of this essay, the question is not what international party group someone belongs or aspires to, what social and political issues they champion, or what economic policies they support. The critical question is whether scholars of political ideology classify such ideological entrepreneurs as liberal, and thus incorporate their writings into a Thai liberal canon. The advantage of this stricter conceptualization of liberalism is that it avoids some of the confusion that otherwise arises from the ubiquitous use of the word "liberal" in different contexts. 


\section{Liberalism in translation}

The study of the history of political thought in Thailand should of course pay attention also to patterns of importation, translation, and publication of political ideas and ideologies from abroad, and their subsequent role in political mobilization, contestation, and legitimation. As is now well understood, the development of the Thai socialist tradition was closely intertwined with the translation and publication of foreign ideological tracts (Kasian 2001). In contrast, Thai conservatism appears rather more parochial. At the very least, the international flow and circulation of ideas that has been so central to the development of Thai socialist thought has no real equivalent in Thai conservatism. ${ }^{4}$ What about liberalism? To address that question, one might, taking inspiration from Kasian (2001), ask to what extent, by whom, when, and why Western liberalism has been "commodified" in Thailand? Fortunately, recent research has begun to shed light on this hitherto otherwise unexplored aspect of Thailand's intellectual history.

The earliest instance of such commodification is to be found in Bangkok Recorder, a newspaper published in Bangkok by the US missionary Dan Beach Bradley from 1865 to 1867. According to one recent study, Bradley was the first to introduce "liberal concepts" to Siam, including "freedom, equality, constitutional and republican government, free press, liberal mind, and meritocracy" (Parkpume 2015, p. 21). These concepts were introduced in connection with “Bradley's patriotic defense of American political values," after Siamese nobles had expressed

\footnotetext{
${ }^{4}$ Or to be more precise: the relevant ideas are less straightforwardly identifiable as political theory or ideology. For instance, Western ideas about religion and Buddhism have played a central role in the construction of Thai conservative ideology. See Jory (2002) and Thongchai (2015).
} 
doubt about their superiority, in light of the American Civil War and the assassination of President Lincoln (Parkpume 2015, p. 27). Bradley's writings frequently angered King Mongkut, and this may perhaps explain the brevity of the newspaper's life. As it seized publication, a window into the Western liberal mind was closed. Bradley would, however, be followed later by other newspapermen who continued the task of making readers in Siam more familiar with foreign political concepts and ideas, such as Thienwan (Vella 1976). However, as members of Siam's conservative elite feared that the genie of liberalism might escape into Siamese society, they tended to repress any such proto-liberal tendencies. The ban on Phraya Suriyanuwat's study in political economy, Sapphasat, is instructive, as was the ban on economics that followed later (Chatthip 1978). That is not to say that there was no scope for ostensibly liberal concepts to enter the public sphere. Newspapers, whose owners and editors were often protected by extraterritoriality rights, could advocate for freedom of opinion and of the press, for instance, and discuss alternative political systems, including constitutional and parliamentary regimes. Sun Yat-Sen's statist political thought appears, however, to have exercised considerably more influence in the era of the absolute monarchy than Western liberalism ever did, and particularly so after the 1911 republican revolution in China (Wasana 2011).

It was only after 1932 that commodification of Western political thought on any larger scale became politically viable. The established literature on the 1932 revolution has tended to downplay the role and influence of Western liberal ideas (Nakharin 1992). Contrasting the 1932 revolution with earlier revolutions in England, America, and France, Amon Raksasat (1972) notes that in all cases but the Siamese were the revolutions put in motion by the development of novel political ideas. But, he points out, "the revolution in Thailand did not begin from our own philosophers and borrowed only very little from European philosophy" (Amon 1972, p. 960). He 
explains this as consequence of the absence, partly but not entirely the result of government repression, of a literary tradition of political fiction and non-fiction writing.

Following the toppling of the absolute monarchy, however, new research suggests that more Western liberalism was brought to the marketplace of ideas than previously recognized. In a pioneering dissertation, Suphachai Suphapol (2013) argues that Rousseau's writings played a particularly important role in the People Party's efforts to establish political-theoretical foundations for the new democratic order's central institutions - constitution, elections, and parliament. It was with this goal in mind that Prince Wan summarized Rousseau's thoughts concerning the "general will" in Khumue rabop mai (Handbook for the new system), published in 1934 (Suphachai 2013, pp. 81-88). In short order thereafter, Rousseau's Discourse on Political Economy, Emile, and The Social Contract were all published in Thai-language versions (Suphachai 2013, p. 292). The Discourse was translated by a collective known as Khana Yuwasan; Emile by Tiang Sirikhan (subsequently a prominent leader of the Free Thai movement and a socialist member of parliament from Isan); and The Social Contract, as compelling circumstantial evidence unearthed by Suphachai suggests, by a young Thammasat University student later known as Chinda Chintanaseri. ${ }^{5}$ In post-revolutionary Siam, Rousseau was thus cultivated as the foremost representative of the Western liberal tradition (Suphachai 2013, p. 152).

As far as we know, no other foreign theorist rivalled Rousseau's standing in Siam after 1932, but Thai intellectuals were certainly curious about Western political philosophy more broadly. Indeed, the newspaper Prachachat had been founded by Prince Wan for the purpose of introducing the Siamese public to liberal-democratic ideas, such as John Stuart Mill's on

\footnotetext{
${ }^{5}$ The Social Contract was published in instalments, now lost, in the newspaper Prachathipatai.
} 
freedom of expression. ${ }^{6}$ And we find a portrait of Voltaire in the student journal Mahawithayalai in 1933 (Pusakon 1933). ${ }^{7}$ A textbook printed in 1935 introduced law students at the recently founded Thammasat University to the idea of the separation of powers, and in doing so cited Western authorities such as Montesquieu, Rousseau, and John Locke (Suphaphon 2013, p. 103, 159). In 1934, Outline of Great Books by J A Hammerton was probably translated into Thai (Suphaphon 2013, pp. 133-134). In addition to Rousseau - who received top billing, as indicated by newspaper advertisements offering readers a chance to pre-order the tome - the translation would have contained summaries of a number of classic Western works of political theory, including Plato's Republic, Aristotle's Politics, More's Utopia, Hobbes' Leviathan, Hume's Essays, moral and political, and Paine's The rights of man. While they are not mentioned in the advertisement, we do know that the original furthermore included summaries of works by a number of key figures in the Western liberal tradition, including John Locke, John Stuart Mill, Walter Bagehot, and Herbert Spencer. As the Thai translation cannot be located, we must surmise either that all original copies have been lost or that it never went to print, perhaps because there were too few pre-orders to make the publication financially viable. The latter scenario is probably the most likely, ${ }^{8}$ suggesting that demand for Western philosophizing remained limited also in post-revolutionary Siam.

\footnotetext{
${ }^{6}$ The discussion of John Stuart Mill in Prachachat was subsequently referenced in a journal for university teachers. See Phrariamwirachaphak (1932). I am grateful to Akekalak Chaiyapumee for providing me with this citation.

${ }^{7}$ Thanks to Puli Fuwongcharoen for bringing this to my attention.

${ }^{8}$ Suphachai Suphaphol, personal communication, 14 February 2017.
} 
While Rousseau is an example of a Western liberal thinker who is successfully commodified in Siam in the 1930s, he appears to be an exception. Demand for publications in the Anglo-American liberal tradition, such as those by John Stuart Mill, appears to have been effectively non-existent - not only in the 1930s but also for many decades thereafter. Given the Francophone orientation of many of the leading Siamese intellectuals of the 1930s, it is perhaps not entirely surprising that Anglo-American liberals had little natural appeal, but it is striking that thinkers like Benjamin Constant and Alexis de Tocqueville made no discernible impact on Siamese political discourse in the immediate post-revolutionary period.

As far as we can tell, Thai engagement with Western political thought is very limited in the period from 1947 to the early 1970s, with the notable exception of a boom in Marxist theorizing during a brief period of political liberalization in the late 1940s and early 1950s (Kasian 2001) (see Table 1).

\section{Table 1: Thai translations of major Western political theorists}

\begin{tabular}{ll}
\hline Year & Author (Title)* \\
\hline 1935 & Jean Jacques Rousseau (Discourse on political economy) \\
\hline 1936 & Jean Jacques Rousseau (Emile; Social contract [no exact date of publication]) \\
\hline 1937 & Adolf Hitler (Mein Kampf) \\
\hline 1948 & Stalin (Problems of Leninism) \\
\hline 1950 & Stalin (Dialectical and historical materialism) \\
\hline 1954 & Engels (The origin of the family, private property and the state) \\
\hline 1964 & Plato (Euthyphro, Apology, Crito, Phaedo) \\
\hline 1966 & Isaiah Berlin (Two concepts of liberty) \\
\hline 1971 & Plato (Meno) \\
\hline 1973 & Plato (Symposium); Niccolo Machiavelli (The Prince) \\
\hline 1974 & Thomas More (Utopia); Jean Jacques Rousseau (The social contract) \\
\hline 1976 & Friedrich Nietzsche (Twilight of the Idols, or, How to Philosophize with a Hammer) \\
\hline 1979 & Alexis de Tocqueville (Democracy in America, vol 1) \\
\hline 1980 & Alexis de Tocqueville (Democracy in America, vol 2); Plato (Republic) \\
\hline 1981 & Plato (Euthyphro, Apology, Crito) \\
\hline 1985 & Montesquieu (The spirit of the laws) \\
\hline
\end{tabular}




\begin{tabular}{ll}
\hline 1987 & $\begin{array}{l}\text { John Stuart Mill (On liberty); Alexander Hamilton, James Madison, and John Jay } \\
\text { (The federalist papers) }\end{array}$ \\
\hline 1990 & Plato (Hippias major) \\
\hline 1991 & Plato (Charmides; Laches; Lysis) \\
\hline 1993 & Henry David Thoreau (Civil disobedience) \\
\hline 1995 & Niccolo Machiavelli (The Prince) \\
\hline 1997 & Friedrich Nietzsche (Thus spoke Zarathustra) \\
\hline 1999 & Karl Marx (Capital) \\
\hline & $\begin{array}{l}\text { Plato (The last days of Socrates [Euthyphro, Apology, Crito, Phaedo]); Jean Jacques } \\
\text { Rousseau (The social contract; Discourse on the arts and sciences; Discourse on the } \\
\text { origin and basis of inequality among men) }\end{array}$ \\
\hline
\end{tabular}

Note: *Authors widely recognized as belonging to the liberal canon have been highlighted in bold.

Sources: Suphachai (2013); Kasian (2001); and author's research.

In the years leading up to the student-led revolt against the military dictatorship in October 1973 signs of an intellectual spring can be seen in the translation of politically "safe" texts by the ancient Greeks, especially Plato, and some careful attempts to introduce Western liberal thought to the Thai public. For instance, Isaiah Berlin's 1958 lecture on “Two concepts of liberty" was translated by Sulak Sivaraksa in 1966 (see Sulak 1967, p. 140). A year later, Saneh Chamarik's translation of M J Harman's Political thought: From Plato to the present was published - the first (but not last) of its kind to be released in Thai.

After the military regime was toppled in 1973, paving the way for a brief experiment in democracy and ideological liberalization, a leading student organization approached Chinda Chintanaseri and asked him to translate The Social Contract. He did so quickly, probably based on notes from the translation that he had produced for serialization in Prachathipatai newspaper almost 40 years earlier, and the book was released in 1974 (Suphachai 2013, pp. 172-175).

Compared with the 1930s, the passion for Rousseau appears to have been less of an exception in the 1970s. The Social Contract finds company with More's Utopia and Machiavelli's The Prince (both translated by Sombat Chanthornwong, a student of the Straussian 
political theorist Harry Jaffa). The first major work of $19^{\text {th }}$ century liberalism to be made available to a broader Thai-language readership is Alexis de Tocqueville's Democracy in America, the two volumes of which were published in 1979 and 1980. The translator, Wiphawan Tuwayanon recalls that it was Saneh Chamarik who asked her to help translate the book from the original French sometime after the massacre at Thammasat University on 6 October 1976 had put a bloody end to the Bangkok spring. ${ }^{9}$

From the mid 1980s to the mid 1990s Thailand experienced an unprecedented economic boom which eventually paved the way for a return to full-blown democracy. It is perhaps not surprising that demand for liberalism in translation during this period reaches hitherto unprecedented levels, with key works by Montesquieu, John Stuart Mill, Henry David Thoreau, and (again) Machiavelli being made available to Thai readers.

During and following the Thaksin era, which began with a remarkable election victory in January 2001 and ended in a September 2006 military coup, Rousseau experienced a third Thai revival. It was initiated by Thaksin himself. During his graduate studies in Texas, he had been introduced to Western political philosophers such as Hobbes, Rousseau, Montesquieu, and Locke (Thak 2007, p. 59). After his political triumph, however, it was with Rousseau above others that he sought to associate his political project (McCargo and Ukrist 2005, p. 99). Indeed, in 2005 he put Rousseau's The Social Contract - as the sole representative of Western political theory - on his list of 109 books that he recommended all Thais to read (Banphitsanulok 2005). However, it was only after the military coup in September 2006, that the Rousseau renaissance is reflected in another round of commodification, with new translations of several of his key works, including, The Social Contract, appearing in 2007 (Suphachai 2013, p. 216).

\footnotetext{
${ }^{9}$ Interview in Bangkok, 9 November 2016.
} 
This quick survey of the history of the commodification of liberalism in Thailand reveals a number of interesting patterns. The first is immediately apparent: the extraordinary enthusiasm for Rousseau, and the striking lack of interest in the rest of the liberal canon. How might that be explained? In his dissertation, Suphachai attributes this to two main factors. The first is Rousseau's rousing rhetoric, as reflected in the opening lines of The Social Contract: "Man is born free; and everywhere he is in chains. One thinks himself the master of others, and still remains a greater slave than they." Particularly in the 1930s and 1970s, Rousseau's rhetoric appealed to the poetic and romantic sensibilities of those who had sought to shake off their chains by overthrowing old regimes. The second, and related, reason is the unrivalled prestige and charisma that Rousseau's name enjoyed because his work was understood to have served as the ideational driving force of the French Revolution. And that revolution was the world historical event above all others with which radical intellectuals wanted to associate the revolutions of 1932 and 1973 (Suphachai 2013, p. 238-239). Thaksin's flirt with Rousseau must thus be understood not as something idiosyncratic, but rather in light of its historical antecedents. The invocation of Rousseau is a recurring trope in radical Thai political discourse. The connection thus forged between the Thaksin government and the 1973 revolution in particular was of course not only discursive, but were manifested also in his close links with a number of prominent former left-wing activists for whom October 1973 and October 1976 were formative political experiences (Kanokrat 2012). The decision to recruit Rousseau to the Thai Rak Thai party may thus be less a matter of Thaksin suddenly remembering his political theory classes at Sam Houston State University, and more a matter of Octobrists seizing the opportunity to recycle Rousseau as an instrument of political legitimation. 
What Suphachai's disertation also makes clear, however, is that Rousseau is a "dual use" weapon. Indeed, the 2007 translation of The Social Contract was published not only because of dissatisfaction with Chinda Chintanaseri's translation from the 1970s, but more importantly to counter the perceived misuse of Rousseau by Thaksin and his supporters (Suphachai 2013, p. 210-213). Parts of Suphachai's dissertation also have a clear ideological ambition: namely, to show that Thaksin, the Red Shirts, and earlier generations of Thai radicals, had a superficial understanding of Rousseau's political philosophy, and that they therefore misused his name and his ideas for purposes of political legitimation. What Suphachai does not recognize, however, are the historical antecedents of this kind of discursive move (i.e., to steal Rousseau's thunder from those threatening the socio-cultural order). In the early 1980s, Thai military ideologues used Rousseau as their theoretical authority when they sought to downplay the role of elections in a democratic system and to assert, in effect, that the Thai monarchy and the military represented the "general will" of the Thai people better than a "parliamentary dictatorship" ever could (see Connors 2007, p. 108).

In fact, this debate has echoes of a much earlier debate in the history of Western political thought, about whether Rousseau was a liberal or a totalitarian. At some point, however, arguments about who is the "true" heir of Rousseau in Thai politics risk becoming faintly ridiculous. Who truly understood what Rousseau had in mind when he published Du contrat social in 1762: the popularly elected Thaksin or the generals who staged the coups in 2006 and 2014? Nevertheless, we can learn a lot about Thai intellectual history and Thai politics simply by paying close attention to when and how Western liberal theorists such as Rousseau have been used (and perhaps abused) in Thai political discourse, by whom, and for what political and ideological ends. 
The second interesting pattern is not immediately apparent, but rather require us to consider the Thai experience in comparative perspective. In world-historical perspective, Thailand's engagement with Western liberal political thought occurs very late. The example of John Stuart Mill’s On liberty (1859) can illustrate. In Japan, “at least sixteen book-length translations of John Stuart Mill” appeared in the period from 1877 to 1895 (Godart 2015 p. 60), and On liberty was of course among them. A Chinese-language edition was published in 1903 (Huang 2008). But it was only in 1987 that On liberty was distributed in Thai, by the National Research Council of Thailand (Mill 1987). What this suggests is that Siam/Thailand remained essentially ideologically self-sufficient for a much longer period than comparable Asian countries that avoided direct colonization. Why that should be the case remains to be explained. But it does reinforce the image, from the previous section, of liberalism's shallow roots in Siamese soil. With a few important exceptions, Thai political and cultural elites did not seek to seriously engage with Western liberal thought for most of the $20^{\text {th }}$ century, and they had little desire to see the Thai public at large do so.

However, it should of course be recognized that the translation of liberalism may be an imperfect gauge of its influence. During the $20^{\text {th }}$ century, an ever-growing circle of welleducated Thais were able to consume Western political theorizing in English and French, should they so desire. And Thailand's political and administrative elites could do so at least since the late 1800s, but we know very little about the influence, if any, of Western liberal thought on them. Who was Vajiravudh referring to when he assured his subjects that his ideas and policies were in perfect agreement with those of the most illustrious European philosophers of political science and law (Saichon 2014a, p. 197)? Is it an echo of the evolutionary theorist Herbert 
Spencer's maxim, "All evil results from the non-adaptation of constitution to conditions," that we hear from the mouth of the king of Siam?

\section{Ripe for liberalism?}

The survey of Thai intellectual history that we have undertaken thus far has traced the rather thin roots of Thailand's liberal tradition. But is liberalism's stunted past also its future? On one level, the prospects for liberalism in Thailand seem bleak indeed. Since the 2014 coup, the ruling junta has set aside basic political liberties (freedom of speech, assembly, etc.) in the name of national security; the rule of man has replaced even the pretence of the rule of law; and civil society and the media have been severely circumscribed in their ability to hold political and economic elites to account. Furthermore, since the passing of King Bhumibol, Thailand has experienced the assertion of an even more aggressively conservative approach to the management of society by the junta and the palace. On the other hand, it is precisely this kind of reactionary overreach that is likely to trigger a liberal counter-reaction. The historical pattern is that public interest in radical and liberal political thought flourishes in the wake of periods of absolutist rule and arbitrary government (whether military or monarchical), and we may thus expect the same to happen if and when a civilian government returns to power in Bangkok.

And we may not even have to wait for that. Developments leading up to and following the 2006 military coup have already convinced many Thai intellectuals that the modern Thai nation-state faces a seemingly intractable crisis of legitimacy, and that conservative efforts to restore national unity through insistent appeals to monarchy, Buddhism, and "Thai values" are failing. Thailand's political crisis is thus fundamentally cultural and ideological. In short, it is a 
crisis of the "traditional" form of Thai nationalism, ${ }^{10}$ and it is manifested in many of the signs of a "disintegrating nation-state" (Haas 2000, pp. 5-6). The search for new solutions to basic political problems accelerated even before the 2014 coup; and the junta that took power then has not succeeded in entirely killing the debate, despite imposing severe restrictions on the freedom of speech and of assembly.

Indeed, the recent Thai-language contributions to the country's intellectual history that I have cited in the previous sections are, as I may already have hinted, very much part of that search. In the pursuit of such an intellectual agenda, the first step has been to try to undermine the cultural symbols that have been used to perpetuate illiberal politics in Thailand over the past few decades. Thus it is that Prajak and Suphachai both seek to disarm rival partisans of their rhetorical weapons. In both cases the critical ammunition is aimed at concepts and phrases that rival camps have dug out from history and recycled (ad nauseam) as political slogans. Suphachai (2013) does so, as already mentioned, by trying to "set the record straight" on what Rousseau really thought about democracy. It is not, he argues, that democratically elected leaders are allowed to bulldoze liberal checks and balances in the name of sanya prachakhom (the social contract) and chetchamnong thuapai (the general will). Prajak (2015) does so by exposing the myth that democracy was a gift from King Prajadhipok to the Thai people that the People's Party squandered and thereby forced his exile and eventual abdication. Prajak carefully traces how the

${ }^{10}$ As Thongchai (2010) has noted, the dominant strategy of adapting Siam/Thailand to the modern world has been one of selective borrowing. The strategy has followed a dualist logic. Thailand's ruling elites have been willing to import technology and formal institutions from abroad, but they have rejected liberal-democratic values as "foreign," and as such fundamentally incompatible with Thai culture. 
final sentence from Prajadhipok's 1935 letter of abdication was turned into fighting words, animating the political struggles of student protesters in 1973 and more recently of the Yellow Shirt movement opposed to the Thaksin "regime." The sentence in question goes as follows: "I am willing to surrender the powers I formerly exercised to the people as a whole, but I am not willing to turn them over to any individual or any group to use in an autocratic manner without heeding the voice of the people" (Batson 1974, pp. 101-102). These royal sentiments have since been turned against both military (Thanom) and parliamentary (Thaksin) "dictatorships" to great effect. But they rest, of course, on a myth that hides the fact that Prajadhipok's disagreement with the 1932 revolutionaries concerned not the power of the people but rather the extent of his personal powers and prerogatives. To move forward politically, Prajak (2015, p. 269) argues, Thailand must find an alternative to this monarchy-centered democracy discourse. ${ }^{11}$

While such critiques are necessary, it is of course also necessary to articulate alternatives. If mainstream conceptions of what Thai politics ought to look like no longer work, what should replace them? Providing answers to that question is the second step of the liberal agenda. Saichon is helpful in this regard as she seeks not only to identify what is wrong with mainstream Thai nationalism, but also to offer some new ways of thinking about what it might mean to be Thai in the $21^{\text {st }}$ century. In the conclusion to 10 panyachon sayam, Saichon thus argues that Thailand's political conflicts can be managed and overcome only if the country can develop a

\footnotetext{
${ }^{11}$ The juxtaposition of Rousseau and Prajadhipok points to an interesting parallel. Arguably, the frames derived from Rousseau and Prajadhipok have been used for similar purposes, besides firing up passionate crowds. Namely, to empower and legitimate the self-appointed true representatives of the Thai people.
} 
new understanding of Thainess. While Saichon doesn't explicitly label her alternative vision of khwam pen phonlameuang thai (Thai citizenship-ness) as such, it is at heart distinctly liberal (in the sense that it resonates with Fawcett's conception of liberalism, mentioned in the introduction). Saichon (2014b, pp. 596-598) posits four main aspects to the cultural reform that Thais should engage in. First, it must be widely recognized that the mainstream conception of Thainess and of the nature of Thai society and culture have become obsolete. Furthermore, it must be recognized that there is a need to develop a new Thai culture in which it is understood that Thainess is not singular and monolithic, but rather allows for a plurality of perspectives and multiple "truths." Saichon understands the resultant pluralism to be a source of political conflict, which cannot be overcome by appeals to samakkhi (unity). Instead, they demand the creation of political institutions that allow for peaceful bargaining and peaceful conflict resolution. Second, Saichon emphasizes the need to change and strengthen the culture of citizenship, putting greater emphasis on rights to equal protection under the law and the equal right and duty to hold state power accountable. Third, Saichon proposes that a new spiritual culture must be cultivated among the citizenry, making them accepting of differences of opinion, and giving them the courage to express their own opinions. Fourth, and finally, Saichon argues for a culture that is based on the recognition of the equality and the dignity of all humans.

While this might seem like a tall order of cultural change, Saichon argues that her intellectual history of the making of Thai national identity shows that Thai panyachon in the past have been able to redefine the meaning of Thainess in response to changing international and domestic circumstances. So they should be prepared to tackle the contemporary challenge with optimism. But where to begin? And from what cultural raw materials might this reformed liberal Thai nationalism be constructed? Saichon preempts that question by recovering, from her history 
of Thai nationalism, ideas and values that were articulated by "conservative" intellectuals as distinctly Thai, but which for historical reasons found no political favor and thus have been forgotten. Prominent among them are Prince Wan's civic conception of the Thai nation (prachachat thai), defined by its citizens having itsara (liberty), as an alternative to the ethnic conception of the Thai nation that successive governments actually cultivated. Other examples include the principles of non-encroachment (khwamprat chak wihingsa) and clever coordination of benefits (khwamchalat nai kanprasanprayot) (Saichon 2014b, pp. 599-601). Given how common it is still today for conservatives to blame Thailand's political woes on the excessive influence of Western liberalism, it may be a clever move to try to anchor distinctly liberal arguments in forgotten aspects of Thailand's conservative tradition.

The intellectual historians that I have highlighted here are of course far from alone in their efforts to fashion a more "liberal" political culture in Thailand. Scholars such as Kasian Tejapira, Thongchai Winichakul, and Somsak Jeamteerasakul are long-standing critics of Thailand's "civic religion," which has proven so amenable to the assertion of illiberal approaches to government (by civilian and military governments alike) (see Suphamit 2012). Members of the Nitirat group of legal scholars have articulated effective critiques of the conservative approach to law that are grounded - explicitly - in the liberal Enlightenment tradition (McCargo and Peeradej 2015). On the religious front, several public intellectuals have in recent years emerged as prominent advocates of the secularization of the Thai state, arguing that it would be better for both Thai democracy and for Buddhism if the sangha (the monastic order) were separated from the state. ${ }^{12}$

\footnotetext{
${ }^{12}$ See for instance, Phiphat (2010), who cites John Stuart Mill extensively, and Vichak (2015). One of the most active advocates of a secular state is the religious scholar Suraphot Thaweesak,
} 
It is quite possible, then, that future generations of intellectual historians interested in liberalism in Thailand may have good reason to pay particularly close attention to developments in Thai political thought during the first two decades of the $21^{\text {st }}$ century. It is in this sense that Thailand is now ripe for liberalism - not as the dominant ideology of government, but as a distinct ideological current (krasae) that should no longer be ignored.

\section{Conclusion}

The intellectual history of Southeast Asia in general and Thailand specifically has often been approached from the perspective of nationalism or Marxism/socialism. In contrast, liberalism, arguably the first modern political ideology (Alexander 2015), has been neglected. There are understandable historical reasons for this lack of scholarly interest. Liberalism has never been a serious contender for the position of either regional master ideology or leading counterhegemonic challenger. Nevertheless, as this essay hopes to have demonstrated, our understanding of the region's past, present, and perhaps future would be enriched if we were to direct our scholarly energies towards a recovery of the history of liberal political thought and political philosophy in Southeast Asia.

This essay has shown that while there are liberals in Thai history, there is no liberalism. This reflects a reluctance to pay systematic attention to ideological entrepreneurs with pronounced liberal inclinations. Among them, Prince Wan - should he be considered Thailand's first liberal intellectual? - stands out as particularly worthy of attention. Indeed, it is quite

who is a frequent commentator on religiopolitical matters on social and mass media, and a regular contributor to Prachathai (http://prachatai.com/category/สุรพศ-ทวีคักดิ์). 
remarkable that a political and intellectual biography of this man, whose considerable influence in Thai cultural life and international affairs spanned the 1932 and 1973 revolutions, has yet to be written (in Thai or English).

The essay has also demonstrated the value of paying close attention to patterns of translation (and citation) of works by lauded liberal thinkers. While much more research on the topic is needed for a comprehensive picture to emerge, what we do know about the history of Thai-language commodification of foreign liberal thought has provided us with an index of the extent to which it has captured the imagination of Thai intellectuals and, perhaps, the wider public as well. As we have seen, liberals have in general not fared too well in this respect. But there are important exceptions. Indeed, a specter has stalked modern Siam - the specter of Rousseau. Further research along these lines is therefore surely warranted, in Thailand and beyond. A comparative question immediately suggests itself: How has Rousseau been received in other Southeast Asian societies, and with what consequences?

Finally, this essay has highlighted how Thai cultural and intellectual historians and other writers have responded to Thailand's troubled political circumstances since 2004 - defined by intense political polarization, intractable conflict, reactionary overreach, and the end the reign of King Bhumibol - by laying the ideological groundwork for the emergence of a liberal form of Thai nationalism. Irrespective of whether such an ideological project ultimately succeeds, future generations of intellectual historians working on liberal thought in Thailand are likely to find an unusually rich set of materials to work with from the first two decades of the $21^{\text {st }}$ century. 


\section{References}

Alexander, James. “The major ideologies of liberalism, socialism, and conservatism”. Political Studies 63, no. 5 (2015): 980-994.

Amon Raksasat. "Kanwang paomai khong kanpatthana prathet thai" [Setting goals for the development of Thailand]. In Thritsadi lae naewkhwamkhit nai kanpatthana prathet [Theory and thought in national development], edited by Amon Raksasat and Khattiya Kannasut. Bangkok: Sathaban banthid patthana borihansat, 1972.

Anderson, Benedict. "Withdrawal symptoms: Social and cultural aspects of the October 6 coup". Bulletin of Concerned Asian Scholars 9, no 3 (1977): 13-30.

Anderson, Benedict. Imagined communities: Reflections on the origin and spread of nationalism. London: Verso, 1990.

Bajpai, Rochana and Carlo Bonura. "South Asian and Southeast Asian ideologies”. In The Oxford handbook of political ideologies, edited by Michael Freeden, Lyman Tower Sargent, and Marc Stears. Oxford: Oxford University Press, 2013.

Banphitsanulok. 109 nangseu khuan an chak nayok thaksin [109 books that you should read, from prime minister Thaksin]. Bangkok: Seetyukhechan, 2005.

Batson, Benjamin A. Siam's political future: Documents from the end of the absolute monarchy. (Data paper no. 96). Ithaca: Southeast Asia Program, Cornell University, 1974.

Bayly, C A. Recovering liberties: Indian thought in the age of liberalism and empire. Cambridge: Cambridge University Press, 2011.

Bell, Duncan. “What is liberalism?” Political Theory 42, no 6 (2014): 682-715. 
Chatthip, Nartsupha. "The economic thought of Phraya Suriyanuwat". In Readings in Thailand's political economy, edited by Vichitvong Na Pombhejara. Bangkok: Bangkok Printing Enterprises, 1978.

Claudio, Lisandro E. Liberalism and the postcolony: Thinking the state in $20^{\text {th }}$ century Philippines. Singapore: NUS Press, 2017.

Connors, Michael K. Democracy and national identity in Thailand. Revised edition. Copenhagen: NIAS Press, 2007.

Connors, Michael K. "Article of faith: The failure of royal liberalism in Thailand." Journal of Contemporary Asia 38, no 1 (2008): 143-165.

Connors, Michael K. "When the walls come tumbling down: The monarchy and Thai-style democracy". Journal of Contemporary Asia 41, no. 4 (2011): 657-673.

Connors, Michael K. "Notes towards an understanding of Thai liberalism.” In Bangkok May 2010: Perspectives on a divided Thailand, edited by Michael J Montesano, Pavin Chachavalpongpun, and Aekapol Chongvilaivan. Singapore: ISEAS Publishing, 2012.

Fawcett, Edmund. Liberalism: The life of an idea. Princeton: Princeton University Press, 2014. Fung, Edmund S K. "Were Chinese liberals liberal? Reflections on the understanding of liberalism in modern China". Pacific Affairs 81, no 4 (2008-9): 557-576.

Godart, G Clinton. "Spencerism in Japan: Boom and bust of a theory". In Global Spencerism: The communication and appropriation of a British evolutionist, edited by Bernard Lightman. Leiden: Brill, 2015.

Haas, Ernst B. Nationalism, liberalism, and progress. Vol 2: The dismal fate of new nations. Ithaca: Cornell University Press, 2000. 
Hewison, Kevin and Kenkij Kitirianglarp. “'Thai-style democracy’: The royalist struggle for Thailand's politics". In Saying the Unsayable. Monarchy and Democracy in Thailand, edited by Søren Ivarsson and Lotte Isager. Copenhagen: Nordic Institute of Asian Studies Press.

Huang, Max Ko-wu. The meaning of freedom: Yan Fu and the origins of Chinese liberalism. Hong Kong: Chinese University Press, 2008.

Jory, Patrick. "Thai and Western Buddhist scholarship in the age of colonialism: King Chulalongkorn redefines the jatakas.” The Journal of Asian Studies 61, no. 3 (2002): 891918.

Jory, Patrick. "Republicanism in Thai history." In A sarong for clio: Essays on the intellectual and cultural history of Thailand, edited by Maurizio Peleggi. Ithaca: Cornell Southeast Asia Program Publications, 2015.

Kanokrat Lertchoosakul. The rise of the Octobrists: Power and conflict among former left wing student activists in contemporary Thai politics. PhD dissertation. London: University of London (London School of Economics and Political Science), 2012.

Kasian Tejapira. Commodifying Marxism: The formation of modern Thai radical culture, 19271958. Kyoto: Kyoto University Press, 2001.

Kershaw, Roger. “The remarkable premiership of M R Kukrit Pramoj”. The Round Table: The Commonwealth Journal of International Affairs 70, no. 279 (1980): 330-335.

Loos, Tamara. "Issaraphap: Limits of individual liberty in Thai jurisprudence". Crossroads: An Interdisciplinary Journal of South East Asian Studies 12, no 1 (1998): 35-75.

McCargo, Duncan and Ukrist Pathmanand. The Thaksinization of Thailand. Copenhagen: NIAS Press, 2005. 
McCargo, Duncan and Peeradej Tanruangporn. "Branding dissent: Nitirat, Thailand's Enlightened Jurists". Journal of Contemporary Asia 45, no. 4 (2015): 419-442.

Mill, John Stuart. Khwamriang wa duai seriphap [On liberty]. Bangkok: Samnakngan khanakammakan wichai haeng chat, 1987.

Moon, Jiyoung. "Liberalism and modern state-building in South Korea". In Contemporary Korean political thought in search of a post-Eurocentric approach, edited by Kang Jung In. Lanham: Lexington Books, 2014.

Murashima, Eiji. "The origin of modern official state ideology in Thailand". Journal of Southeast Asian Studies 19, no 1 (1988): 80-96.

Nakharin Mektrairat. Kanpatiwat sayam pho so 2475 [The 1932 revolution in Siam]. Bangkok: Khrongkan tamra sangkhomsat lae manutsat, 1992.

Nolte, Sharon H. Liberalism in modern Japan: Ishibashi Tanzan and his teachers, 1905-1960. Berkeley: University of California Press, 1987.

Parkpume Vanichaka. "The beginning of liberalism in Thailand: Dan Beach Bradley and Bangkok Recorder". Journal of the Graduate School of Asia-Pacific Studies [Waseda University] 29 (2015): 21-36.

Peleggi, Maurizio. Thailand: The worldly kingdom. London: Reaktion Books, 2007.

Phiphat Phasuthanchat. Rat kap satsana: Botkhwam wa duai anachak satsanachak lae seriphap [State and religion: on the wordly realm, the religious realm, and freedom]. Bangkok: Siam, 2010.

Phrariamwirachapak. "Seriphap somphap lae pharadonphap" [Freedom, equality, brotherhood], Withayachan 32, no 22 (November 1932). 
Prajak Konkirati. Kanmeuang watthanatham thai: wa duay khwam songcham wathakam amnat [Thai cultural politics: On memory, discourse, power]. Bangkok: Fa Diewkan, 2015. Pusakon, "Wontae” [Voltaire], Mahawithayalai, 11, no 5 (1933), pp. 843-848.

Reynolds, Craig J. Thai radical discourse: The real face of Thai feudalism today. Ithaca: Southeast Asia Program Publications, 1994.

Rodan, Garry and Caroline Hughes. The politics of accountability in Southeast Asia: The dominance of moral ideologies. Oxford: Oxford University Press, 2014.

Saichon Sattayanurak. 10 panyachon siam, lem 1 panyachon haeng ratsomburanayasitthirat [Ten Siamese intellectuals, volume 1, Intellectuals of the absolute monarchy]. Bangkok: Open Books, 2014a.

Saichon Sattayanurak. 10 panyachon siam, lem 2 panyachon lang kanpatiwat 2475 [Ten Siamese intellectuals, volume 2, Intellectuals after the 1932 revolution]. Bangkok: Open Books, 2014b.

Sopha Chanamun. "Chat thai" nai thatsana panyachon huakaona [The "Thai nation" in the outlook of progressive intellectuals]. Bangkok: Matichon, 2007.

Sturm, Andreas. The king's nation: A study of the emergence and development of nation and nationalism in Thailand. PhD dissertation. London: University of London (London School of Economics and Political Science), 2006.

Sulak Sivaraksa. Lai seu sayam reu botkhwam nangseuphim tang tang khong so siwarak thi khian tae klap chak prathet angkrit chon theung patchuban (pho so 2505-2510) [Siamese book patterns, or newspaper articles by Sulak Sivaraksa written upon his return from England until now, 1965-1967]. Bangkok: Phraephitthaya, 1967. 
Sungsidh Pirayarangsan, "Phak prachathipat: chak anurak niyom su latthi seriniyom mai" [The Democrat Party: From conservatism to neoliberalism]. In Chitsamnuek lae udomkan khong krabuankan prachathipatai ruam samai [Consciusness and ideology of the contemporary democracy movement], edited by Sungsidh Piriyanrangsan and Pasuk Phongpaichit. Bangkok: Political Economy Studies Center, Chulalongkorn University, 1996.

Suphachai Suphaphon. Kansang khwamniyom lae panha kiewkap kantikhwam tritsadi kanmeuang khong chong chak rutso nai boribot kanmeuang thai [The popularization and the problems of interpretation of Jean Jacques Rousseau's political theory in Thai political context]. PhD dissertation. Bangkok: Chulalongkorn University, 2013.

Suphamit Pitiphat. Botwiphak thammawitthaya haeng phonlameuang khong prakasok ruamsamai: kasian techapira thongchai winitchakun somsak chiamthirasakun [Contemporary prophets and their critiques of Thai civic religion: Kasian Tejapira, Thongchai Winichakul, Somsak Jeamteerasakul]. Bangkok: Khopfai, 2012.

Thak Chaloemtiarana. "Distinctions with a difference: The despotic paternalism of Sarit Thanarat and the demagogic authoritarianism of Thaksin Shinawatra". Crossroads: An Interdisciplinary Journal of Southeast Asian Studies 19, no. 1 (2007): 50-94.

Thanet Aphornsuwan. "Slavery and modernity: freedom in the making of modern Siam". In Asian freedoms: The idea of freedom in East and Southeast Asia, edited by David Kelly and Anthony Reid. Cambridge: Cambridge University Press.

Thongchai Winichakul. "Prawatisat thai baep ratchachatniyom: chak yuk ananikhom amphrang su ratchachatniyom mai rue lathi pho khong kradumphi thai nai patchuban" [Royalist 
nationalist history: From the colonial era to the new royalist nationalism].

Sinlapawatthanatham 23, no. 1 (November 2001): 43-52.

Thongchai Winichakul. "Nationalism and the radical intelligentsia in Thailand". Third World Quarterly 29, no 3 (2008): 575-591.

Thongchai Winichakul. "Coming to terms with the West: Intellectual strategies of bifurcation and post-Westernism in Siam." In The ambiguous allure of the West: Traces of the colonial in Thailand, edited by Rachel V Harrison and Peter A Jackson. Ithaca: Southeast Asia Program Publications, 2010.

Thongchai Winichakul. "Buddhist apologetics and a genealogy of comparative religion in Siam". Numen 62, no. 1 (2015): 76-99.

Thompson, Virginia and Richard Adloff. The left wing in Southeast Asia. New York: William Sloane Associates, 1950.

Tomsa, Dirk. "Regional party networks and the limits of democratic norm diffusion in Southeast Asia”. International Political Science Review 38, no 1 (2017): 128-141.

Vella, Walter F. “Thianwan of Siam: A man who fought giants”. In Papers in honor of Professor Woodbridge Bingham: A Festschrift for his seventy-fifth birthday, edited by James B Parsons. San Francisco: Chinese Materials Center, 1976.

Vichak Panich. Rat-tham-nua [State-dharma-confusion]. Bangkok: Matichon, 2015.

Wasana Wongsurawat. "Thailand and the Xinhai revolution: Expectation, reality, and inspiration". In Sun Yat-Sen, Nanyang and the 1911 revolution, edited by Lee Lai To and Lee Hock Guan. Singapore: ISEAS Publications, 2011.

Zimmerman, Robert F. Reflections on the collapse of democracy in Thailand. Singapore: Institute of Southeast Asian Studies, 1978. 